\title{
INTERAKSI ANTARA FAKTOR TKAM DAN PEMBELAJARAN \\ TERHADAP KEMAMPUAN PENALARAN DEDUKTIF MATEMATIS \\ MAHASISWA CALON GURU SD BESERTA KINERJANYA (Studi Kuasi Eksperimen pada Pembelajaran dengan Pendekatan Induktif)
}

\author{
Dina Mayadiana Suwarma \\ Yaya S. Kusumah
}

\begin{abstract}
Abstrak
Penelitian ini adalah kuasi eksperimen dengan disain kontrol pre dan post tes pada mata kuliah Bilangan terhadap 67 mahasiswa calon guru SD di suatu universitas di Bandung Tahun Akademik 2010/2011. Kelompok eksperimen mendapatkan perlakuan berupa pembelajaran dengan pendekatan induktif. Instrumen yang digunakan terdiri dari: Tes Kemampuan Awal Matematis (KAM), Tes Kemampuan Penalaran Deduktif Matematis (KPDM), pedoman observasi, kamera photo, dan wawancara. Analisis data menggunakan ANOVA dua Jalur. Berdasarkan analisis data diperoleh kesimpulan bahwa: (1) Tidak terdapat interaksi antara faktor TKAM dan pembelajaran terhadap KPDM dan (2) Kemampuan Induksi Matematis tergolong rendah.
\end{abstract}

Kata kunci: Pembelajaran dengan Pendekatan Induktif, Penalaran Deduktif Matematis, Kemampuan Induksi Matematis, dan Mahasiswa calon guru SD.

\section{A. PENDAHULUAN}

Salah satu strategi pengembangan Pendidikan Guru Sekolah Dasar (PGSD) adalah penyediaan pendidik berkompeten pada SD sehingga: (1) Tersedianya, terjangkaunya, dan terjaminnya kepastian memperoleh layanan Pendidikan Dasar berkualitas dan (2) Tersedianya dan terjangkaunya layanan Pendidikan Dasar yang berkualitas dan relevan. Dengan tercapainya tujuan ini, Indonesia memiliki faktor-faktor penentu keunggulan suatu negara sehingga lahirlah insan-insan Indonesia yang cerdas, unggul, dan kompetitif.

Terkait masalah teknis mengenai aspek kualitas dalam pembelajaran matematika di PGSD, hasil studi pendahuluan Mayadiana (2008) terhadap 37 mahasiswa PGSD UPI Kampus 1 dan 39 mahasiswa PGSD UPI Kampus 2 kelas konsentrasi matematika reguler pada Kemampuan Penalaran Deduktif Matematis (KPDM) menggunakan tes yang diadopsi dan diadaptasi dari soal KPDM Rbayans (2007)

a. 94,74\% memiliki skor $10(\mathrm{SM}=23)$ untuk KPDM. Hal ini berarti, hampir seluruh mahasiswa PGSD memiliki KPDM rendah.

b. Rata-rata skor KPDM PGSD UPI Kampus 2 lebih besar daripada PGSD UPI Kampus 1 yaitu selisih 3. Namun, keduanya memiliki KPDM rendah.

Hasil studi deskriptif Mayadiana (2010) terhadap 47 mahasiswa PGSD UPI Kampus 3 semester satu pada Mata Kuliah Konsep Dasar Matematika terkait soal matematika yang memuat aspek Menyusun Kesimpulan mereka juga sangat sulit untuk menyusun kesimpulan dari premis yang diberikan. 
Rendahnya KPDM hasil studi pendahuluan Mayadiana (2008) dan studi deskriptif Mayadiana (2010) membuktikan mahasiswa bermasalah dalam kemampuan penalaran matematis. Padahal, terdapat rekognisi NCTM (2006) terhadap penalaran dan pembuktian sebagai aspek dasar dalam matematika dan pengembangan pengetahuan matematis baru melalui pemecahan masalah.

Diperlukan satu lingkungan belajar yang dapat memfasilitasi mahasiswa untuk mengembangkan kemampuan penalaran. Menurut Sumarmo (2010), pembelajaran inovatif terbukti dapat mengembangkan kemampuan berpikir dan disposisi matematis. Salah satu pembelajaran yang dapat memfasilitasi mahasiswa untuk mengembangkan kemampuan penalaran adalah Pembelajaran dengan Pendekatan Induktif (PI). Hal ini merujuk pada pendapat Hariyono dan Supriyono (2009) mengenai pembelajaran dengan pendekatan induktif sebagai pembelajaran yang dapat mengembangkan kemampuan berpikir mahasiswa. Hal ini dipertegas oleh pendapat Anderson (2009) mengenai aktivitas pada pendekatan induktif dapat memotivasi mahasiswa untuk menstimulasi kepenasaran dan mendorong mereka untuk mengeksplorasi ide sendiri. Pada pembelajaran dengan pendekatan ini, dosen adalah sumber informasi tetapi bukan satu-satunya sumber. Siapapun yang terlibat dalam kelompok diskusi dapat berkontribusi dalam proses belajar mengajar.

Berdasarkan KPDM dan pembelajaran dengan pendekatan induktif (PI), terdapat suatu relevansi untuk menciptakan dan mengembangkan lingkungan belajar matematika yang menantang, menarik, dan mudah sehingga KPDM mahasiswa terasah. Peneliti memandang penting kiranya melakukan penelitian kuasi eksperimen terhadap KPDM mahasiswa calon guru SD kelas konsentrasi matematika reguler. Jenis penelitian kuasi eksperimen dengan disain kelas kontrol pretes-postes dilakukan untuk mengumpulkan data guna menjawab rumusan masalah berikut.

Berdasarkan latar belakang masalah, rumusan masalah sebagai berikut:

1. Apakah terdapat interaksi antara pembelajaran dan Tingkat Kemampuan Awal Matematis (TKAM) mahasiswa dalam menghasilkan KPDM mahasiswa?

2. Bagaimana gambaran aktivitas mahasiswa selama proses pembelajaran dengan pendekatan induktif berlangsung ditinjau dari penyelesaian soal KPDM.

Berdasarkan rumusan masalah, tujuan diadakannya penelitian ini sebagai berikut:

1. Mendeskripsikan dan menganalisis hasil penelitian secara komprehensif mengenai interaksi antara pembelajaran dan TKAM untuk menghasilkan KPDM mahasiswa.

2. Mendeskripsikan dan menganalisis hasil penelitian secara komprehensif mengenai aktivitas mahasiswa selama proses pembelajaran dengan pendekatan induktif berlangsung ditinjau dari penyelesaian soal KPDM.

\section{B. Tinjauan Teoretis}

\section{Penalaran Deduktif Matematis}

Penalaran deduktif adalah kegiatan berpikir untuk menarik suatu kesimpulan deduktif atau melakukan inferensi deduktif (Rich, 2005). Serupa dengan Rich dan 
NCTM, Sumarmo (2010) mendefinisikan penalaran deduktif sebagai penarikan kesimpulan berdasarkan aturan yang disepakati. Nilai kebenaran dalam penalaran deduktif bersifat mutlak benar atau salah dan tidak keduanya bersama-sama. Penalaran deduktif dapat tergolong tingkat rendah atau tingkat tinggi. Secara lengkap kegiatan yang tergolong pada penalaran deduktif menurut Sumarmo (2010) di antaranya adalah:

1. Melaksanakan perhitungan berdasarkan aturan atau rumus tertentu.

2. Menarik kesimpulan logis berdasarkan aturan inferensi, memeriksa validitas argumen, membuktikan, dan menyusun argumen yang valid.

3. Menyusun pembuktian langsung, pembuktian tak langsung dan pembuktian dengan Induksi matematika.

Menurut Rapar (1996), inferensi deduktif terdiri dari inferensi langsung dan inferensi tidak langsung atau inferensi silogisme. Hal ini senada dengan Matlin (1994) yang membagi penalaran deduktif menjadi dua bagian yaitu conditional reasoning dan silogisme. Di sisi lain, Rich (2006) menyatakan pengambilan kesimpulan deduktif disebut penalaran silogistik karena ketiga pernyataan pada langkah penalaran ini bersama-sama membentuk suatu silogisme.

Kaanginan (2007) menegaskan Bukti Langsung adalah cara menentukan kebenaran pernyataan jika $\mathrm{p}$ maka $\mathrm{q}$ dengan memisalkan $\mathrm{p}$ benar dan upaya penggunaan definisi, sifat, dalil, atau hukum yang telah diterima kebenarannya sehingga diperoleh q benar. Contoh soal bukti langsung adalah:

Bukti:

$$
\text { Buktikan }-(-a)=a \text { untuk } a \text { Bilangan Bulat. }
$$

$$
\begin{aligned}
-(-a) & =-(-a)+0 & & \text { (Sifat Identitas Jumlah Bilangan Bulat) } \\
& =-(-a)+(-a)+a & & \text { (Sifat Invers Jumlah Bilangan Bulat) } \\
& =(-(-a)+(-a))+a & & \text { (Sifat Asosiatif Jumlah Bilangan Bulat) } \\
& =0+a & & \text { (Sifat Invers Jumlah Bilangan Bulat) } \\
& =a & & \text { (Sifat Identitias Jumlah Bilangan Bulat) }
\end{aligned}
$$

Terbukti.

Namun, tidak semua pembuktian dapat dilakukan dengan pembuktian langsung karena akan menjadi sangat rumit. Cara lain yang dapat digunakan untuk pembuktian validitas argumentasi adalah pembuktian tidak langsung. Pembuktian ini terdiri dari kontrapositif dan kontradiksi (Kaanginan, 2007). Bukti dengan kontrapositif didasarkan pada hubungan $(p \Rightarrow q) \Leftrightarrow(\sim q \Rightarrow \sim p)$. Dengan memisalkan $\sim$ q benar, mahasiswa berupaya memperlihatkan $\sim$ p benar. Karena $\sim$ q $\Rightarrow \sim \mathrm{p}$ tautologi dengan $\mathrm{p} \Rightarrow \mathrm{q}$ maka dengan memperlihatkan $\sim \mathrm{q} \Rightarrow \sim \mathrm{p}$ benar maka $\mathrm{p} \Rightarrow \mathrm{q}$.

Bukti tak langsung sebenarnya merupakan gabungan antara bukti kondisional dan pengertian kontradiksi. Bukti ini dikenal juga sebagai bukti dengan kontradiksi atau reductio and absurdum. Dengan menggunakan Modus Tollen dapat diturunkan negasi dari antesenden suatu pernyataan kondisional apabila diketahui konsekwen bernilai salah. Jika konsekwen tersebut suatu kontradiksi maka diketahui secara logika adalah salah. Jadi, dari $\mathrm{p} \Rightarrow(\mathrm{q} \wedge \sim \mathrm{q})$ dapat diturunkan $\sim \mathrm{p}$. 
Pembuktian dengan kontradiksi nampak pada contoh pembuktian validitas argumentasi berikut.

Bukti:

$$
\begin{aligned}
& \sim \mathrm{q} \vee \mathrm{r} \\
& \mathrm{p} \Rightarrow \sim \mathrm{r} \\
& \mathrm{q} \\
& \therefore \sim \mathrm{p}
\end{aligned}
$$

$\begin{array}{ll}\text { 1. } \sim \mathrm{q} \vee \mathrm{r} & \text { Premis } \\ \text { 2. } \mathrm{p} \Rightarrow \sim \mathrm{r} & \text { Premis } \\ \text { 3. } \mathrm{q} & \text { Premis } \\ \text { 4. } \quad \mathrm{p} & \text { Premis } \\ \text { 5. } \sim \mathrm{r} & \text { 2,4 Modus Ponen } \\ \text { 6. } \sim \mathrm{q} & \text { 1,5 Silogisme Disjungsi } \\ \text { 7. } \mathrm{q} \wedge \sim \mathrm{q} & \text { 3,6 Konjungsi } \\ \text { 8. } \mathrm{p} \Rightarrow \mathrm{q} \wedge \sim \mathrm{q} & \text { 4,7 BK } \\ \text { 9. } \sim \mathrm{p} & \text { 8 Kontradiksi }\end{array}$

Tidak semua konjektur dibuktikan menggunakan counter example tunggal. Contohnya pernyataan:

$$
1+3+5+\ldots+(2 n-1)=\mathrm{P}(n)=n^{2} \text { berlaku untuk } n \text { Bilangan Asli }
$$

Lucas (1990) menyatakan induksi matematis merupakan bentuk langsung dari penalaran deduktif untuk memverifikasi generalisasi mengenai bilangan bulat. Langkah induksi matematis adalah:

1. Tunjukkan $\mathrm{P}(n)$ benar untuk $n=1$. $n=1, \mathrm{P}(1)=1$ dan 1 Bilangan Bulat.

2. Misalkan untuk $n=k, \mathrm{P}(k)$ benar.

$\mathrm{P}(k)$ benar berarti $1+3+\ldots+(2 k-1)=\mathrm{k}^{2}$.

3. Tunjukkan untuk $n=k+1, \mathrm{P}(k+1)$ benar.

$$
\begin{aligned}
\mathrm{P}(k+1) & =1+3+\ldots+(2 k-1)+(2(k+1)-1) \\
& =k^{2}+2 k+1 \\
& =(k+1)^{2}
\end{aligned}
$$

$\mathrm{P}(k+1)$ benar.

Terbukti $\mathrm{P}(n)$ benar untuk $n$ Bilangan Asli.

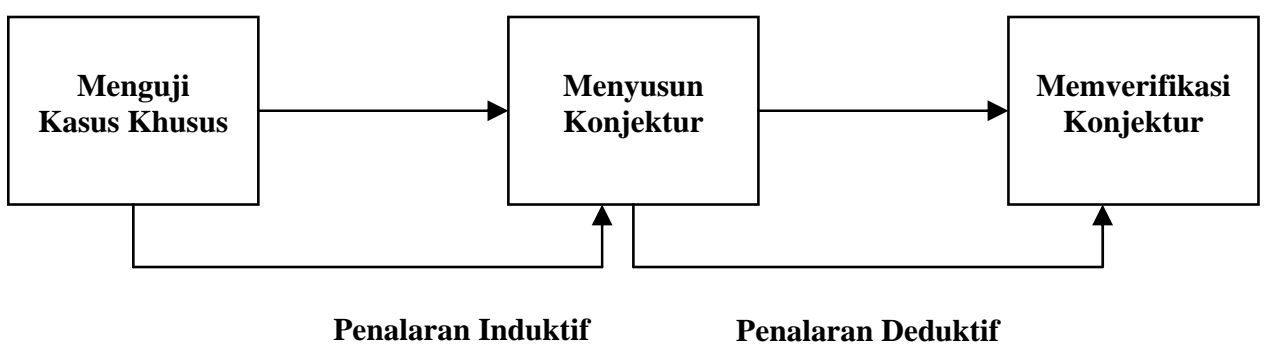

Gambar 1: Hubungan Penalaran Induktif, Konjektur, dan Penalaran Deduktif 
Induksi matematika tiap langkah sudah ada aturannya. Mahasiswa biasanya mengalami kesulitan pada langkah ketiga. Langkah pembuktian ini jelas memperlihatkan hubungan antara penalaran induktif, konjektur, dan penalaran deduktif. Hubungan ini nampak pada Gambar 1.

\section{Pembelajaran Matematika dengan Pendekatan Induktif}

Pendekatan induktif dalam pembelajaran merupakan warisan sejak masa awal Yunani. Dua tokoh terkenal yang mendukung pendekatan ini adalah Socrates dan Brunner. Metode Socrates menekankan pada pentingnya penalaran induktif dan komunikasi pada proses pembelajaran sedangkan Brunner menekankan pada pentingnya pembelajaran penemuan dan bagaimana dosen dapat membantu mahasiswa menjadi konstruktivis atau pembentuk pengetahuan (Prince dan Felder, 2006).

Sharan dan Sharma (2008) menegaskan bahwa pendekatan induktif didasarkan pada proses induksi. Pertama-tama ambil beberapa contoh kemudian generalisasikan. Pendekatan induktif adalah metode untuk mengkonstruksi rumus dengan bantuan sejumlah contoh nyata (Sharan dan Sharma, 2008). Induksi berarti menyediakan kebenaran umum dengan menunjukkan bahwa ia benar untuk kasus tertentu. Ia juga benar untuk seluruh kasus. Mahasiswa mengikuti materi pelajaran dengan minat dan pemahaman tinggi. Mahasiswa dapat memahami seluruh proses secara rinci. Pada pendekatan ini, mahasiswa membentuk pengetahuan dari beberapa rumus atau prinsip melalui fakta-fakta, contoh, dan eksperimen. Jadi pengetahuan yang dibentuk melalui metode ini menjadi solid dan berdurasi serta perbedaan kekuatan mental mahasiswa dapat dikembangkan. Oleh karena itu, pendekatan ini merupakan aliran psikologi alamiah.

Anderson (2009) mempertegas bahwa pendekatan yang diawali dengan melibatkan situasi khusus bermakna sehingga kesimpulan atau prinsip umum dikembangkan kemudian reaksi dan pengalaman mahasiswa merupakan pendekatan induktif dalam proses belajar mengajar. Pendekatan ini mengilustrasikan pengetahuan, minat, pengamatan, dan opini mahasiswa. Aktivitas ini mendorong mahasiswa menemukan hubungan dan fakta-fakta penting serta prinsip-prinsip oleh dirinya sendiri. Aktivitas ini juga memotivasi mahasiswa untuk dapat menstimulasi kepenasaran dan mendorong mereka untuk mengeksplorasi ide sendiri. Dosen adalah sumber informasi tetapi bukan satu-satunya sumber. Siapapun dalam kelompok dapat berkontribusi dalam proses belajar mengajar dengan pendekatan ini.

Tabel 1 menunjukkan perbedaan dan kesamaan karakteristik lima pembelajaran yang berinduk pada pembelajaran dengan pendekatan induktif. Pembelajaran ini terdiri dari Inkuiri (I), Berbasis Masalah (BM), Berbasis Proyek (BP), Berbasis Kasus (BK), Discovery (D), dan Just in Time Teaching (JTT).

Beberapa contoh pembelajaran dengan pendekatan induktif adalah pembelajaran inkuiri, pembelajaran berbasis masalah, pembelajaran berbasis proyek, pembelajaran berbasis kasus, dan pembelajaran Just in Time Teaching (Prince dan Felder, 2006). Karakteristik setiap pembelajaran dan intensitasnya nampak pada Tabel 5.1 (Prince dan Felder, 2006). 
Tabel 1

Kesaman Karakteristik Pembelajaran Induktif

\begin{tabular}{|c|c|c|c|c|c|c|}
\hline Metode & I & $\mathbf{B M}$ & BP & BK & $\mathbf{D}$ & JTT \\
\hline \multicolumn{7}{|l|}{ Karakteristik } \\
\hline Pertanyaan atau permasalahan yang menyediakan konteks untuk belajar & 1 & 2 & 2 & 2 & 2 & 2 \\
\hline $\begin{array}{l}\text { Menyediakan masalah kompleks, terbuka, open ended dunia nyata } \\
\text { sebagai konteks untuk belajar. }\end{array}$ & 4 & 1 & 3 & 2 & 4 & 4 \\
\hline Menyediakan proyek utama sebagai konteks untuk belajar. & 4 & 4 & 1 & 3 & 4 & 4 \\
\hline Menyediakan studi kasus sebagai konteks untuk belajar. & 4 & 4 & 4 & 1 & 4 & 4 \\
\hline Siswa menemukan isi pembelajaran oleh dirinya sendiri. & 2 & 2 & 2 & 3 & 1 & 2 \\
\hline $\begin{array}{l}\text { Siswa menyelesaikan dan memberikan latihan konseptual secara } \\
\text { elektronik: guru mengatur pembelajaran berdasarkan respon siswa. }\end{array}$ & 4 & 4 & 4 & 4 & 4 & 1 \\
\hline Secara primer merupakan pembelajaran self-directed. & 4 & 3 & 3 & 3 & 2 & 4 \\
\hline Pembelajaran aktif. & 2 & 2 & 2 & 2 & 2 & 2 \\
\hline Pembelajaran kooperatif atau kolaboratif (berdasarkan & 4 & 3 & 3 & 4 & 4 & 4 \\
\hline
\end{tabular}
kelompok).

1 - menurut definisi, 2 - selalu, 3 - biasanya, 4 - mungkin

Terdapat pula perbedaan diantara pembelajaran induktif ini yaitu hasil akhir dari tugas berbasis proyek adalah sejenis tulisan formal atau laporan lisan sedangkan hasil akhir pembelajaran inkuiri terbimbing bisa berupa jawaban sederhana dari pertanyaan yang menarik, seperti: "Mengapa telur menjadi lebih lama direbus di daerah dingin daripada di daerah panas?”. Perbedaan lainnya adalah pembelajaran berbasis kasus dan berbasis masalah melibatkan analisis yang luas mengenai skenario nyata atau hipotesis sedangkan pembelajaran Just in Time Teaching meminta mahasiswa menjawab pertanyaan dan menyimak isi bacaan pada website sebagai bahan pelajaran.

\section{Metode Penelitian}

Berdasarkan alur penelitian, penelitian ini adalah kuasi eksperimen dengan disain kelompok kontrol tes awal tes akhir (Craswell, 1994; Drew, Hardman, dan Hosp, 2008). Disain yang dimaksud nampak pada Tabel 2.

Tabel 2

Disain Penelitian

\begin{tabular}{|c|c|c|c|c|}
\hline Kelompok & Pemilihan & Tes Awal & Perlakuan & Tes Akhir \\
\hline Eksperimen & Acak & O & X & O \\
\hline Kontrol & Acak & O & & O \\
\hline
\end{tabular}

Keterangan:

O : Tes Awal/Akhir KPIM, KPDM, dan KPMKM

$\mathrm{X} \quad$ : Pembelajaran dengan Pendekatan Induktif

Subyek populasi yang dipilih dalam penelitian ini adalah seluruh mahasiswa calon guru SD suatu universitas di Bandung. Berdasarkan karakteristik populasi yang telah ditetapkan, pengambilan sampel kelas pada kampus daerah suatu universitas di Bandung dilakukan secara acak dari kelas yang ada. Hal ini dilakukan untuk memilih sebuah kelompok eksperimen dan kontrol. Dengan demikian, subyek penelitian ini adalah 67 mahasiswa calon guru SD semester enam pada kampus daerah suatu universitas di Bandung.

Mahasiswa ini dipilih sebagai sampel penelitian dengan pertimbangan: 
1. Mahasiswa telah lulus Mata Kuliah Konsep Dasar Matematika, Pendidikan Matematika 1, dan Pendidikan Matematika 2.

2. Mahasiswa berada di Kelas Konsentrasi Matematika hampir satu semester sehingga sudah terbiasa dengan situasi pembelajaran di kelas ini.

Mahasiswa diasumsikan memiliki kemampuan Awal Matematis yang lebih homogen.

Sampel ini terbagi menjadi kelompok eksperimen terdiri dari 31 mahasiswa dan kelompok kontrol terdiri dari 36 mahasiswa. Untuk menjamin validitas internal dari penelitian ini maka kedua kelompok mesti memiliki kesetaraan tertentu yang dapat diukur melalui Tes Kemampuan Awal Matematis (TKAM). Data pada penelitian ini dianalisis menggunakan Microsoft Office Excel 2007 dan SPSS 18,0 dengan tingkat kepercayaan 95\%.

\section{Hasil Penelitian dan Pembahasan}

\section{Interaksi antara Faktor TKAM dan Pembelajaran terhadap KPDM}

Skor Tes Akhir KPDM berdasarkan pembelajaran maupun berdasarkan pembelajaran ditinjau dari TKAM telah memenuhi asumsi normalitas dan homogenitas varians. Hasil Uji ANOVA Dua Jalur untuk skor ini disajikan pada Tabel 3.

Tabel 3

Uji ANOVA Dua Jalur Skor Tes Akhir Kemampuan Penalaran Deduktif Matematis dengan Faktor Pembelajaran dan TKAM

\begin{tabular}{|c|c|c|c|c|c|}
\hline Sumber & JK & $\mathbf{d k}$ & RJK & $\mathbf{F}$ & $p$ \\
\hline Inter & 27874,789 & 1 & 27874,789 & 13573,152 & 0,00 \\
\hline Pembelajaran (A) & 105,870 & 1 & 105,870 & 51,552 & 0,00 \\
\hline TKAM (B) & 123,338 & 2 & 61,669 & 30,029 & 0,00 \\
\hline$A * B$ & 0,489 & 2 & 0,245 & 0,119 & 0,89 \\
\hline Error & 125,274 & 61 & 2,054 & & \\
\hline Total & 39955,000 & 67 & & & \\
\hline
\end{tabular}

Ada tidaknya interaksi antara pembelajaran dan TKAM terhadap kemampuan penalaran deduktif matematis dapat dilihat pada Gambar 1. Bila dianalisis secara grafis, gambar ini menunjukkan tidak ada interaksi antara pembelajaran dan TKAM terhadap kemampuan penalaran deduktif matematis. Hal ini dikarenakan ruas garis yang terbentuk pada pembelajaran untuk tiap TKAM nampak tidak berpotongan.

$\mathrm{H}_{0}: \mu_{p i t}-\mu_{p k t}=\mu_{p i s}-\mu_{p k s}=\mu_{p i r}-\mu_{p k r}$.

$\mathrm{H}_{\mathrm{a}}$ : paling tidak ada satu selisih yang berbeda secara signifikan dari yang lainnya.

Kriteria pengujian: $P>0,05$ terima $\mathrm{H}_{0}$.

Bila dianalisis secara statistik, ada tidaknya interaksi nampak pada hasil Uji ANOVA Dua Jalur pada Tabel 3, interaksi antara pembelajaran dan TKAM terhadap kemampuan penalaran deduktif matematis memiliki nilai $p>0,05$ sehingga $\mathrm{H}_{0}$ diterima. Ini berarti tidak terdapat interaksi antara pembelajaran (PI dan PK) dengan TKAM (atas, tengah, dan bawah) dalam menghasilkan kemampuan penalaran deduktif matematis mahasiswa. Dengan kata lain, tidak terdapat perbedaan yang signifikan antara selisih kemampuan penalaran deduktif matematis mahasiswa yang memperoleh pembelajaran dengan pendekatan unduktif pada TKAM atas, tengah, dan bawah dan mahasiswa yang memperoleh pembelajaran konvensional pada TKAM atas, tengah, dan bawah. 


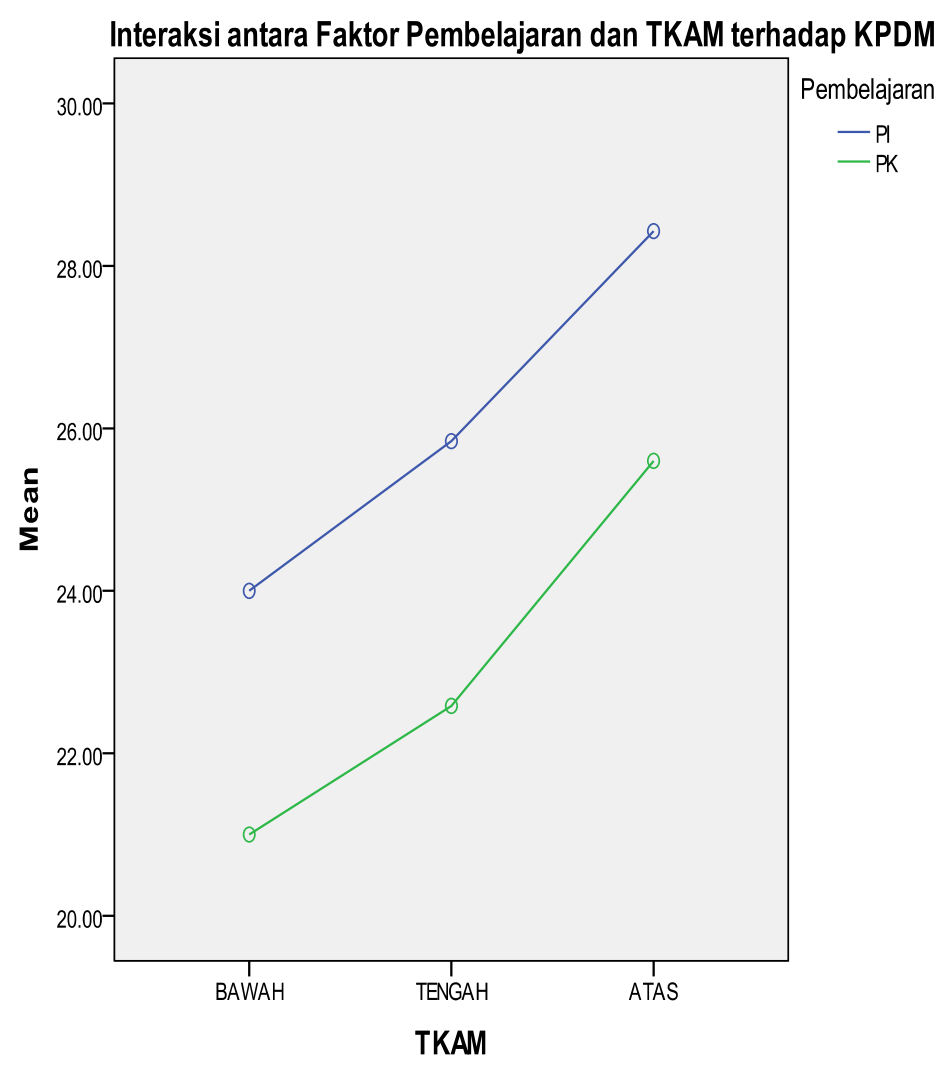

Gambar 2: Interaksi Pembelajaran dan TKAM terhadap Kemampuan Penalaran Deduktif Matematis Mahasiswa

Kesimpulannya, secara umum pembelajaran tidak memberikan pengaruh yang signifikan terhadap TKAM dalam mengembangkan kemampuan penalaran deduktif matematis mahasiswa. Berdasarkan Tabel 3 dan analisis pada pembelajaran, terbukti bahwa Faktor pembelajaran lebih dominan dalam menghasilkan perbedaan KPDM mahasiswa daripada faktor TKAM.

\section{Kinerja Mahasiswa dalam Menyelesaikan Soal KPDM}

Tes ini terdiri dari soal nomor 1 memuat aspek Bukti Langsung (BL), nomor 2 memuat aspek Kontradiksi (KD), nomor 3 memuat aspek Kontrapositif (KP), nomor 4 memuat aspek Induksi Matematika (IM), dan nomor 5 memuat aspek Induksi Matematika (IM). Rekapitulasi kinerja KPDM mahasiswa untuk tiap nomor disajikan pada Gambar 3. 


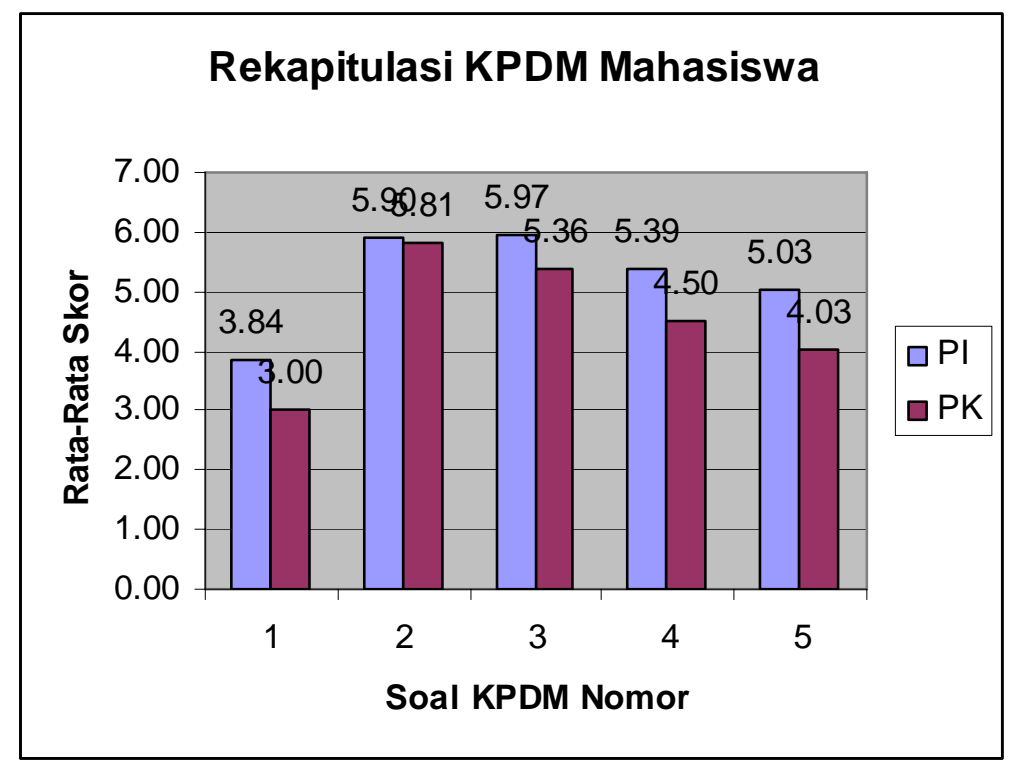

Gambar 3: Rekapitulasi Kinerja KPDM Mahasiswa

Untuk soal nomor 1, mahasiswa yang memperoleh pembelajaran dengan pendekatan induktif memiliki skor terkecil 0 dan skor terbesar $4(\mathrm{SM}=4)$. Dari hasil perhitungan diperoleh rata-rata 3,84 dan simpngan baku 0,73. Kemampuan BL mahasiswa ini termasuk ke dalam kategori tinggi. Mahasiswa yang memperoleh pembelajaran konvensional memiliki skor terkecil 0 dan skor terbesar $4(\mathrm{SM}=4)$. Dari hasil perhitungan diperoleh rata-rata 1,71 dan simpngan baku 1,00. Kemampuan BL mahasiswa ini termasuk ke dalam kategori rendah. Selisih rata-ratanya adalah 2,13. Dari jawaban yang diberikan oleh mahasiswa nampak bahwa mereka lupa tentang definisi keterbagian. Dari wawancara terungkap bahwa mereka merasa sulit untuk menghubungkan pernyataan yang ada. Selain itu, mereka juga lupa akan definisi dan sifat yang relevan untuk menyelesaikan soal bukti langsung ini.

Untuk soal nomor 2, mahasiswa yang memperoleh pembelajaran dengan pendekatan induktif memiliki skor terkecil 4 dan skor terbesar $6(\mathrm{SM}=6)$. Dari hasil perhitungan diperoleh rata-rata 5,90 dan simpngan baku 0,40. Kemampuan KP mahasiswa ini termasuk ke dalam kategori tinggi. Mahasiswa yang memperoleh pembelajaran konvensional memiliki skor terkecil 3 dan skor terbesar $6(\mathrm{SM}=6)$. Dari hasil perhitungan diperoleh rata-rata 5,80 dan simpngan baku 0,62. Kemampuan KP mahasiswa ini termasuk ke dalam kategori tinggi. Selisih rata-ratanya adalah 0,10. Dari jawaban yang diberikan oleh mahasiswa nampak bahwa ada mahasiswa yang lupa dengan langkah-langkah pembuktian dengan metode KP.

Untuk soal nomor 3, mahasiswa yang memperoleh pembelajaran dengan pendekatan induktif memiliki skor terkecil 4 dan skor terbesar $8(\mathrm{SM}=10)$. Dari hasil perhitungan diperoleh rata-rata 5,97 dan simpngan baku 1,02. Kemampuan KD mahasiswa ini termasuk ke dalam kategori sedang. Mahasiswa yang memperoleh pembelajaran konvensional memiliki skor terkecil 0 dan skor 
terbesar 8 (SM = 10). Dari hasil perhitungan diperoleh rata-rata 5,36 dan simpngan baku 1,17. Kemampuan KD mahasiswa ini termasuk ke dalam kategori rendah. Selisih rata-ratanya adalah o,61. Soal KPDM nomor 3 memiliki tingkat kesukaran sukar. Oleh karena itu hanya beberapa orang saja yang memperoleh skor maksimal. Dari jawaban mahasiswa nampak bahwa masih ada yang llupa dengan definisi Bilangan Rasional dan langkah pembuktian dengan metode KD.

Untuk soal nomor 4, mahasiswa yang memperoleh pembelajaran dengan pendekatan induktif memiliki skor terkecil 4 dan skor terbesar $7(\mathrm{SM}=10)$. Dari hasil perhitungan diperoleh rata-rata 5,39 dan simpngan baku 0,95. Kemampuan IM mahasiswa ini termasuk ke dalam kategori rendah. Mahasiswa yang memperoleh pembelajaran konvensional memiliki skor terkecil 2 dan skor terbesar 8 (SM = 10). Dari hasil perhitungan diperoleh rata-rata 4,50 dan simpngan baku 1,23. Kemampuan IM mahasiswa ini termasuk ke dalam kategori rendah. Selisih rata-ratanya adalah 2,13. Dari jawaban yang diberikan oleh mahasiswa nampak bahwa mereka lupa tentang definisi keterbagian. Dari wawancara terungkap bahwa mereka lupa dengan langkah pembuktian dengan IM dan mengalami kesulitan pada langkah 3 yaitu membuktikan $\mathrm{P}(n)$ benar untuk $n=$ $k+1$. Hal ini dikarenakan mereka tidak punya ide untuk mengubah hasil perhitungannua ke dalam bentuk hasil $\mathrm{P}(k+1)$.

Untuk soal nomor 5, mahasiswa yang memperoleh pembelajaran dengan pendekatan induktif memiliki skor terkecil 3 dan skor terbesar $7(\mathrm{SM}=10)$. Dari hasil perhitungan diperoleh rata-rata 5,03 dan simpngan baku 1,08. Kemampuan IM mahasiswa ini termasuk ke dalam kategori rendah. Mahasiswa yang memperoleh pembelajaran konvensional memiliki skor terkecil 1 dan skor terbesar $8(\mathrm{SM}=10)$. Dari hasil perhitungan diperoleh rata-rata 4,02 dan simpngan baku 1,34. Kemampuan IM mahasiswa ini termasuk ke dalam kategori rendah. Selisih rata-ratanya adalah 1,01. Dari jawaban yang diberikan oleh mahasiswa nampak bahwa mereka lupa tentang definisi keterbagian. Dari wawancara terungkap bahwa mereka lupa dengan langkah pembuktian IM dan mengalami kesulitan pada langkah 3 yaitu membuktikan $\mathrm{P}(n)$ benar untuk $n=k$ +1 . Hal ini dikarenakan mereka tidak punya ide untuk mengubah hasil perhitungannua ke dalam bentuk hasil $\mathrm{P}(k+1)$.

Dalam pembelajaran induktif, mahasiswa didorong untuk melakuakan kegiatan yang sejalan dengan tahapan yang termuat dalam proses pembelajaran Miyouka (Mayadiana, 2009) yang memuat tahapan generalisasi termasuk generalisasi abstrak berupa prinsip atau teorema terkait konsep yang dipelajari. Tahapan ini adalah:

a. Memberikan contoh dan bukan contoh dari definisi atau konsep yang akan dikonstruksi. Langkah ini memberi kesempatan kepada mahasiswa untuk melakukan brainstorming sehingga muncul ide yang relevan dengan konsep yang akan dikonstruksi.

b. Menganalisis presentasi contoh yang disajikan. Melalui beragam ide berupa contoh dan bukan contoh dari konsep yang akan dikonstruksi, mahasiswa difasilitasi untuk melakukan penalaran analogi dan investigasi guna mengeksplorasi kesamaan dan ketakserupaan ciri dari beragam ide yang muncul. 
c. Menyusun definisi atau sifat-sifat konsep berdasarkan presentasi contoh yang disajikan. Berdasarkan kegiatan penalaran analogi dan investigasi, mahasiswa diarahkan untuk menyusun generalisasi dari contoh yang memiliki kesamaan ciri. Pada tahap ini mahasiswa dituntut untuk bisa mengkonstruksi konsep yang dipelajari sehingga mereka terlatih untuk membentuk konsep matematika yang telah ada.

d. Menguji dan memverifikasi definisi atau sifat-sifat yang telah dikonstruksi melalui contoh berbeda. Hasil dari kegiatan generalisasi, mahasiswa diarahkan untuk menerapkan definisi atau sifat yang terbentuk melalui penyusunan contoh serupa yang memenuhi definisi atau sifat ini. Selain itu, mereka juga diberi kesempatan untuk mengkonstruksi masalah sendiri berdasarkan konsep yang telah dikonstruksi.

Berdasarkan rata-rata skor tes akhir KPDM pada pembelajaran dengan pendekatan induktif ini nampaknya masih belum optimal. Hal ini didukung oleh data penelitian yang menunjukkan bahwa Kualitas KPDM mahasiswa yang memperoleh PI termasuk kualifikasi sedang. Dengan langkah pembelajaran ini, mahasiswa dirangsang untuk mempelajari konsep matematika secara bermakna. Hal ini dikarenakan untuk mempelajari konsep baru, mahasiswa mesti menghubungkan konsep baru tersebut dengan konsep yang sudah dipelajari sebelumnya.

Pembelajaran dengan pendekatan induktif pun termasuk ke dalam pembelajaran inovatif karena dikembangkan berdasarkan model berpikir induktif sehingga dapat memfasilitasi untuk mengembangkan kemampuan berpikir mahasiswa. Selain itu, pembelajaran ini juga merupakan induk dari pembelajaran berbasis masalah, pembelajaran penemuan, pembelajaran berbasis kasus, dan Just in Time Teaching.

\section{E. Kesimpulan, Implikasi, dan Saran \\ 1. Kesimpulan}

Kesimpulan yang dapat ditarik dari penelitian tentang pengembangan Kemampuan Penalaran Deduktif Matematis (KPDM) mahasiswa calon guru SD melalui Pembelajaran dengan Pendekatan Induktif (PI) adalah:

1. Tidak terdapat interaksi antara pembelajaran (PI dan PK) dan Tingkat Kemampuan Awal Matematis (TKAM) terhadap pencapaian KPDM mahasiswa. Berarti secara bersamaan faktor pembelajaran dan TKAM tidak memberikan pengaruh yang signifikan terhadap kemampuan penalaran deduktif matematis. Faktor pembelajaran lebih dominan dalam menghasilkan KPDM mahasiswa.

2. Gambaran Kinerja Mahasiswa Ditinjau dari proses penyelesaian soal KPDM.

Pada saat menyelesaikan soal tes KPDM, mahasiswa merasa pusing dan enggan untuk menyelesaikan soal yang memuat banyak variabel. Mereka sulit untuk menjelaskan hubungan antar pernyataan matematika yang dibuatnya, dan masih ada yang menyelesaikan soal Induksi Matematika (IM) hanya menggunakan contoh saja.

\section{Implikasi}

Implikasi dari penelitian ini adalah:

1. Tidak adanya interaksi antara faktor pembelajaran dan TKAM terhadap KPDM dalam pembelajaran dengan pendekatan induktif menunjukkan bahwa pembelajaran 
tidak berinteraksi dengan kemampuan awal matematis mahasiswa tetapi pembelajaran berinteraksi dengan mahasiswa yang belajar.

2. Pembelajaran dengan pendekatan induktif lebih efektif jika didukung oleh pemahaman yang baik akan konteks dan soal yang disajikan sehingga mahasiswa dapat mengomunikasikan ide guna mengeksplorasi dan menemukan konsep secara mudah, tepat, dan jelas.

\section{Saran}

Rekomendasi terkait implikasi penelitian adalah bahwa perlu redisain terhadap tahapan pembelajaran dengan pendekatan induktif pada penelitian selanjutnya untuk mengembangkan kemampuan induksi matematika mahasiswa calon guru SD. Redisain dapat dilakukan dengan merujuk pada tahapan generalisasi yang lebih tepat dan sederhana sebagai interaksi secara iteratif dalam merevisi pengetahuan melalui abstraksi yang sesuai.

\section{Daftar Pustaka}

Anderson, E. W. (2009). The Inductive Approach to Teaching Start Learning Process with The Individual and Personal Interest of Pupils. Journal of Cooperative Extention. Approach to Effective Teaching 2009.

Christon, C. dan Papageorgiau, E. (2007). A Framework of Mathematics Inductive Reasoning. Journal Learning and Istruction. Cyprus. Elsevier, Ltd. 17(2007).

Hariyono, E. dan Supriyono. (2009). Implementation Lesson Study Effort as Improve Process and Result Teaching and Learning in Physics Departmen. Prosiding Seminar Internasional FPMIPA UNESA Tanggal 18-19 Agustus 2009.

Kaanginan, M. (2007). Cara Cerdas Belajar Matematika. Jakarta. Grafindo.

Lucas, J. F. (1990). Introduction to Abstract Mathematics. USA. Ardsley House Publishers Inc.

Mayadiana, D. (2008). Studi Pendahuluan Kemampuan Penalaran dan Pemecahan Masalah Kreatif Matematika Mahasiswa Calon Guru SD. Makalah; Tidak diterbitkan.

Mayadiana, D. (2009). Integrasi Pembelajaran Matematika Induktif dan Analogi untuk setiap Level Generalisasi Mahasiswa Calon Guru SD. Prosiding KOPENDAS Tingkat Internasional. UPI Kampus Sumedang 2009.

Mayadiana, D. (2010). Kemampuan Penalaran Deduktif dan Pemecahan Masalah Open Ended Matematika Mahasiswa Calon Guru SD. Makalah: Tidak diterbitkan.

NCTM. (2009). Reasoning and Proof. \{Online\}. Tersedia: http://www.nctm.org/standards/content.aspx?id=2686. (9 Juli 2011).

Rapar, J. A. (2005). Pengantar Filsafat. Yogyakarta. Kanisius.

Rapar, J. A. (2006). Pengantar Logika Asas-Asas Penalaran Sistematis Yogyakarta. Kanisius.

Rbayans. (2007). Penalaran Deduktif dalam Matematika. [Online]. Tersedia:http://rbaryans.wordpress.com/2007/05/01/penalaran-deduktif dalam-matematika/. (2 Juni 2011). 
Rich, B. (2005). Geometri Schaum's Easy Outlines Belajar Super Cepat. Jakarta. Erlangga.

Sharan, R. dan Sharma, M. (2008). Teaching of Mathematics. New Delhi. APH Publishing Company.

Starcko, A. J. (1995). Creativity in Classroom. Logman. USA.

Sumarmo, U. (2010). Berfikir dan Disposisi Matematik: Apa, Mengapa, dan Bagaimana dikembangkan pada Peserta Didik.

Yunus, M. (2007). Logika suatu Pengantar. Yogyakarta. Graha Ilmu.

\section{BIODATA PENULIS}

Dina Mayadina adalah dosen Prodi PGSD FIP Universitas Pendidikan Indonesia Bandung. Penulis menyelesaikan S-3 Program Pendidikan Matematika pada Sekolah Pascasarjana Universitas Pendidikan Indonesia.

Yaya S. Kusumah adalah Guru Besar FPMIPA UPI. Penulis tercatat sebagai dosen pada Program Studi Pendidikan Matematika (S-3) pada Sekolah Pascasarjana Universitas Pendidikan Indonesia. 